\title{
NOTES
}

\section{The Influence of the Precipitation Rate on the Properties of Porous Chromia}

\section{SUMMARY}

The properties were studied of heated $\left(320^{\circ} \mathrm{C}\right)$ chromia samples, prepared by two precipitation methods:

(1) addition of ammonia to chromium salt solutions,

(2) $\mathrm{OH}^{-}$formation in chromium salt solutions through hydrolysis of urea.

Samples formed by means of the first method are macro or mesoporous and have a lower specific surface area $\left(\sim 200 \mathrm{~m}^{2} \cdot \mathrm{g}^{-1}\right)$ than those formed by urea hydrolysis $\left(\sim 300 \mathrm{~m}^{2} \cdot \mathrm{g}^{-1}\right)$. Only in the case of a very slow addition of the ammonia solution these properties of the chromia's become equal. Experiments show that the micro porous type samples with high surface area are only formed if the $\mathrm{pH}$ range 5.1 to 5.7 is passed slowly. The formation of polychromium complexes of uniform size is suggested.

\section{INTRODUCTION}

The influence of the rate of ammonia addition to a solution of chromium nitrate has been studied by Kohlschuitter (1). He observed that the rate of ammonia addition influenced the $\mathrm{pH}$ value as a function of the amount of base added. Also the chromium hydroxides formed at different precipitation rates differed in sedimentation volume, in rate of solution in acid and in adsorption properties.

Burwell (2) found that precipitation of hydrous chromium oxide by means of hydroxyl-ions, produced by hydrolysis of urea, yielded a chromia sample with a high specific surface area of about $300 \mathrm{~m}^{2} \cdot \mathrm{g}^{-1}$ [while $200 \mathrm{~m}^{2} \cdot \mathrm{g}^{-1}$ is obtained after precipitation with ammonia (3)]. Burwell, however, stated that slow addition of ammonia gave "similar results" as homogeneous precipitation $(4,5)$. Later on Sing et al. studied the properties of hydrous chromia, precipitated in different ways, with respect to the formation of $\alpha$ chromia (6) and the pore structure after heating (7).

We studied the influence of the addition rate of ammonia, as well as that of the rate of urea hydrolysis on the surface area of chromia, its pore structure and some other properties.

\section{EXPERIMENTAL}

In all experiments we use a $0.038 \mathrm{~m}$ chromiumnitrate solution in water at $95 \pm 1{ }^{\circ} \mathrm{C}$. Variation of the rate of precipitation was induced by different urea concentrations (between 0.038 and $0.125 \mathrm{~m}$ ) or by a different rate of addition of ammonia solution to the chromium nitrate solution (between 70.6 and $3.1 \mathrm{ml} \mathrm{min}-1$ of $0.1 \mathrm{~m}$ ammonia was added to a $750 \mathrm{ml}$ of chromium solution). In some experiments ammonia addition was interrupted at chosen $\mathrm{pH}$ values during $4 \mathrm{hr}$ and in some other experiments the rate of ammonia addition was changed during precipitation. In all experiments the reaction was carried out with continuous stirring until the solution showed the $\mathrm{pH}$ value of about 8.3 . The $\mathrm{pH}$ of the solutions were always measured after cooling to $20^{\circ} \mathrm{C}$. The resulting precipitates were washed 4 times by decantation, filtered and dried in air at $110^{\circ} \mathrm{C}$ during $96 \mathrm{hr}$.

Surface areas of the gels were calculated from the adsorption isotherm of argon at liquid nitrogen temperature with the aid of the BET equation, after the gels had been outgassed in vacuum during $16 \mathrm{hr}$ at $320^{\circ} \mathrm{C}$. Pore structures of the gels as well as their surface areas were determined with the aid of $t$-plots [Lippens and de Boer (8)]. Differential thermal analysis and thermogravimetric analysis were carried out by heating the samples in air from 20 to $600^{\circ} \mathrm{C}$ with a rate of $1^{\circ} \mathrm{C}$ per minute. The catalytic characterization of the different chromia samples has been obtained by means of the hydrogenation of cis-2pentene at $275^{\circ} \mathrm{C}$ by means of a pulse technique. Activation of the oxides took place by outgassing during $16 \mathrm{hr}$ at $320^{\circ} \mathrm{C}$ in vacuum and by heating in a hydrogen stream at $345^{\circ} \mathrm{C}$ during $2 \mathrm{hr}$.

\section{RESULTS}

The values of the surface areas of the chromia samples prepared by both methods were determined as a function of precipitation time, i.e., the time needed to obtain precipitation at about $\mathrm{pH}=5.8$; see Fig. 1 . The results show that at equal precipitation times the surface area of chromia formed by urea hydrolysis exceeds that of chromia precipitated by means of ammonia. Both area's increase at increasing precipitation times. The surface area of samples formed by means of very slowly addition of ammonia approximates that of chromia samples formed by means of hydrolysis. The same applies for the pore volume. Table I gives the pore volumes, the mean pore radii and the surface area's calculated with the aid of $t$-plots. All chromia's precipitated by means of hy- 
TABLE I

Pore Volumes, Mean Pore Radi and C-Values of Different Precipitated Chromia's After OUtgasstng During 16 HR. AT $320^{\circ} \mathrm{C}$

\begin{tabular}{|c|c|c|c|c|c|c|}
\hline $\begin{array}{c}\text { Type of } \\
\text { precipitation }\end{array}$ & $t_{\mathrm{prec}}(\min )$ & $S_{\mathrm{BET}}\left(\mathrm{m}^{2} \cdot \mathrm{g}^{-1}\right)$ & $C_{\mathrm{BET}}$ & $S_{t}\left(\mathrm{~m}^{2} \cdot \mathrm{g}^{-1}\right)$ & $V_{\text {pore }}\left(\mathrm{cm}^{3} \cdot \mathrm{g}^{-1}\right)$ & $\bar{r}_{\text {pores }}(\AA)$ \\
\hline & 100 & $280 \pm 10$ & 100 & 270 & 0.108 & 4.0 \\
\hline hydrolysis & 180 & $302 \pm 14$ & 145 & 253 & 0.104 & 4.1 \\
\hline \multirow[t]{3}{*}{ of urea } & 216 & $328 \pm 10$ & 145 & & & \\
\hline & 330 & $338 \pm 10$ & 180 & 295 & 0.113 & 3.8 \\
\hline & 11.5 & $204 \pm 9$ & 60 & & & \\
\hline addition & 100 & $220 \pm 10$ & 70 & 202 & abt 0.21 & abt 10 \\
\hline \multirow[t]{2}{*}{ of ammonia } & 240 & $238 \pm 10$ & 80 & 225 & abt 0.18 & abt 8 \\
\hline & 720 & $310 \pm 5$ & 70 & 290 & 0.156 & 5.4 \\
\hline
\end{tabular}

a Mean values of two or three measurements.

drolysis proved to be microporous $\left(\dot{r}_{\text {pore }}=\right.$ abt. $\left.4 \AA\right)$. The mean pore radii of the samples precipitated with ammonia tend to approximate these values for microporous structures in case the addition of ammonia proceeds very slowly. Two samples precipitated by the two methods, which have about the same surface area and mean pore size show, however, different values of the $C$ constant of the BET equation; see Table I. This fact points to the presence of relative more micropores in the samples precipitated by hydrolysis of urea.

We measured BET surface areas from outgassed chromias $\left(320^{\circ}\right)$ after interruption of the ammonia addition for $4 \mathrm{hr}$ at $\mathrm{pH}$ values of $3.0,3.8,4.3,4.6$, and 5.3. The influence of these equilibrations were not large, $225 \pm 10 \mathrm{~m}^{2} \cdot \mathrm{g}^{-1}$ and values did not show a trend. A slow decrease of the $\mathrm{pH}$ was always observed after the interruption of the ammonia addition (e.g., from $\mathrm{pH} 5.3$ to 5.1 within $4 \mathrm{hr}$ ).

In one experiment an increase of the $\mathrm{pH}$ from 2.2 to 3 within $15 \mathrm{sec}$ was obtained by rapid addition of ammonia to the chromium nitrate solution. By slow addition of $3 \mathrm{ml} 0.1 \mathrm{~m} \mathrm{NH}_{3}$ per minute the $\mathrm{pH}$ value amounted 6 after $2 \mathrm{hr}$. Rapid addition of am-

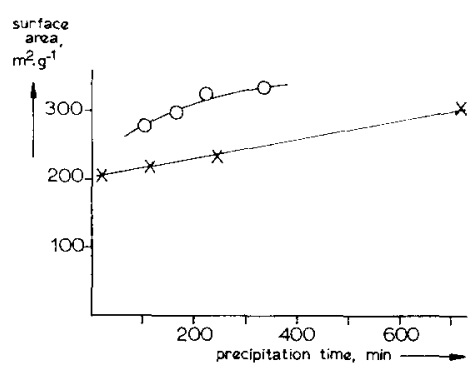

FIG. 1. Specific surface areas of chromia samples as a function of the precipitation time. O-urea hydrolysis, $X$-addition of ammonia. monia to the suspension increased $\mathrm{pH}$ to 8.3 within $15 \mathrm{sec}$. The chromia sample exposed a surface area of $320 \mathrm{~m}^{2} \cdot \mathrm{g}^{-1},(C=44)$. In a second experiment after a slow addition of ammonia $\left(3 \mathrm{ml} \cdot \mathrm{min}^{-1}\right.$ during $\left.3 \mathrm{hr}\right)$ to $\mathrm{pH} 3$, by means of a rapid addition of ammonia within $15 \mathrm{sec} \mathrm{pH}=8.3$ was reached. The surface area of the chromia obtained was only $175 \mathrm{~m}^{2} \cdot \mathrm{g}^{-1}(C=50)$.

TGA and DTA measurements, determination of $\mathrm{X}$-ray diffraction between $20^{\circ}$ and $500^{\circ} \mathrm{C}$ as well as measurements of the specific catalytic hydrogenation activity did not show any differences between chromia samples formed by the two methods.

\section{DISCUSSION}

Data in Fig. 1 and Table I show that when decreasing the rate of ammonia addition the resulting chromia resembles more and more that formed by means of urea hydrolysis. This confirms the nondocumented statement of Burwell mentioned before $(4,5)$. The authors learned that J. W. Geus observed the same phenomenon in precipitating hydrous alumina (9).

From the results of the experiments where ammonia addition was interrupted at various $\mathrm{pH}$ values we may conclude that formation of microporous chromia with a high surface area only occurs provided that either the $\mathrm{pH}$ is changing slowly in the range of $\mathrm{pH} 5.3$ to about 5.8 or that the precipitation itself occurs very slowly. The fact that during the hydrolysis of urea the formation of the precipitate begins suddenly and seems to be completed within a few minutes indicates that the first mentioned factor may be the most important.

The formation of solvated polyoxocomplexes from aqueous chromium salt at lower $\mathrm{pH}$ values is generally accepted. After precipitation and drying at $110^{\circ} \mathrm{C}$ the structure contains much water (i.e., $1.5-5 \mathrm{~mol}_{2} \mathrm{O}$ per $\mathrm{Cr}$ atom), which after expellance by heating in air to $300^{\circ} \mathrm{C}$ diminishes to about $0.5 \mathrm{H}_{2} \mathrm{O}$ per $\mathrm{Cr}$ 
atom leaving a pore volume corresponding with $0.4 \mathrm{H}_{2} \mathrm{O}$ per $\mathrm{Cr}$ atom. Matijevic and Bell (10) observed the formation of hydrous chromia particles with a narrow size distribution $\left(\sim 10^{4} \AA\right)$ when heating a chromium salt solution at $75^{\circ} \mathrm{C}$ and $\mathrm{pH} \approx 3$. This may suggest that in our case slow addition of ammonia leads to the formation of solvated polyoxocomplexes of rather uniform size.

Quick addition of alkali leads to a fast agglomeration of particles of different sizes to a "random" network. The precipitate contains large and small water containing holes, which provides large as well as small pores.

Hence a low rate of increase of $\mathrm{pH}$ just before precipitation provides (typically shaped) polycomplexes which after precipitation and heating will form a microporous structure with a large surface area.

\section{CONCLUSIONS}

(i) By means of slow addition of ammonia to a chromium salt solution the same microporous chromia (surface area $300 \mathrm{~m}^{2} \cdot \mathrm{g}^{-1}$ ) can be formed as by means of hydrolysis of urea (see Fig. 1 and Table I).

(ii) The main condition for the formation of such a chromia is that the $\mathrm{pH}$ region 5.3 to 5.8 is passed slowly; only in this case large polychromiumoxocomplexes are formed which will be the building blocks for the precipitate from which microporous chromia can be formed.

\section{REFERENCES}

1. Kohischütter, H. W., Angew. Chem. 49, 865 (1936).
2. Burwelt, R. L., JR., ANd Cornett, D., J. Am. Chem. Soc. 90, 2489 (1968).

3. Derén, J., Haber, J., Burzyk, J., and PodGORECKA, A., J. Catal. 2, 161 (1963).

4. Burweli, R. L., JR., Haller, G. L., Taylor, K. C., ANd ReAd, J. F., Adv. Calal. 20, 1 (1969).

5. Burweli, R. L., Littlewood, A. B., Carden, M., Pass, G., and Stoddart, C. T, H., J. $A m$. Chem. Soc. 82, 6272 (1960).

6. Carruthers, J. D., Fenerty, J., and Sing, K. S. W., Proc. oth Intern. Symp. Reactivity of Solids, p. 127, Schenectady, 1968.

7. Baker, F. S., Carruthers, J. D., Day, R. E., Sing, K. S. W., and Strijker, L. J., Disc. Faraday Soc. no. 52 (1972), p. 173.

8. LIPPENS, B. C., AND DE BoeR, J. H., J. Catal. 4, 319 (1965).

9. GEUS, J. W., private communication.

10. Matijevic, E., ANd Bell, A., in "Particle Growth in Suspensions" (A. L. Smith, Ed.), Symp. Brunel Univ. 1972, p. 179, Academic Press, 1973.

J. Sonnemans, ${ }^{*}$ H. de Keijzer, and P. Mars

Twente University of Technology

Department of Chemistry

P.O. Box 217; Enschede, The Netherlands

Received November 18, 1974; accepted January 15, 1975

* Present address: AKZO Chemie B. V., Nieuwendammerkade, Amsterdam. 